This study compares the signal transduction pathway which leads to the upregulation of intercellular adhesion molecule-1 (ICAM-1) expression with that of the increase in the expression of inducible nitric oxide synthase (iNOS) protein and activity caused by endotoxin in cultured J774.2 macrophages. Treatment of $\mathbf{J} 774.2$ cells with lipopolysaccharide $\boldsymbol{E}$. coli (LPS) induced a concentration-dependent increase in the expression of ICAM-1 on the cell surface within $4 \mathrm{~h}$ and an increase in iNOS protein and activity at $24 \mathrm{~h}$. The upregulation of ICAM-1 expression on J774.2 macrophages caused by LPS was significantly inhibited by pretreatment of the cells with inhibitors of the activation of the nuclear transcription factor NF- $\kappa$ B, such as L-1-tosylamido-2-phenylethylchloromethyl ketone (TPCK), pyrrolidine dithiocarbamate (PDTC), rotenone or calpain inhibitor I, but not by the tyrosine kinase inhibitors, tyrphostin AG126 or genistein. In contrast, genistein or tyrphostin AG126 also prevented the induction of iNOS protein and activity in J774.2 macrophages elicited by LPS. Thus, the increase in the expression of ICAM-1 on J774.2 macrophages by endotoxin involves the activation of $\mathrm{NF} \kappa \mathrm{B}$, but not of protein tyrosine kinase.

Key words: Inflammation, ICAM-1, iNOS, NF-KB, Protein tyrosine kinase, Macrophages

\section{Upregulation of ICAM-1 expression on J774.2 macrophages by endotoxin involves activation of NF- $k B$ but not protein tyrosine kinase: comparison to induction of iNOS}

\author{
Hartmut Ruetten, ${ }^{1,3, C A}$ Christoph Thiemermann ${ }^{1}$ and \\ Mauro Perretti ${ }^{2}$
}

Departments of ${ }^{1}$ Cardiovascular Pharmacology and ${ }^{2}$ Biochemical Pharmacology, The William Harvey Research Institute, St. Bartholomew's and the Royal London School of Medicine and Dentistry, Charterhouse Square, London EC1M 6BQ, UK

${ }^{\mathrm{CA} C o r r e s p o n d i n g}$ Author
${ }^{3}$ Present address: Hoechst Marion Roussel, DG
Cardiovascular Diseases, 65926 Frankfurt am Main,
Germany.
Tel: (+49) 6930581242
Fax: (+49) 6930526875
Email: hartmut.ruetten@hmrag.com

\section{Introduction}

Intracellular adhesion molecule-1 (ICAM-1; CD54) is a 90-kDa inducible cell surface glycoprotein that promotes leukocyte adhesion in inflammatory conditions. ${ }^{1,2}$ Analysis of ICAM-1 complementary deoxyribonucleic acid sequence revealed it to be a member of the immunoglobulin gene superfamily. ${ }^{3}$ ICAM-1 is expressed basally at low levels on many cell types, including endothelial cells, macrophages, myocytes, and vascular smooth muscle cells, ${ }^{4-7}$ but can be induced to high levels by stimulation with lipopolysaccharide (LPS), phorbol ester, or inflammatory cytokines, such as tumour necrosis factor- $\alpha$ (TNF- $\alpha$ ) or interleukin-1 $\beta$ (IL-1 $\beta$ ). For that concerning cells of the mono-myelocytic lineage, ICAM-1 expression on the plasma membrane of macrophages is higher than that measured on circulating monocytes. ${ }^{8}$ Nonetheless, ICAM-1 is not only a marker of differentiation, and its expression can also be up-regulated following cell activation, such as after treatment with IL-1 $\beta$ of U-937 cells or of murine macrophages. ${ }^{9}$ The second messenger pathways responsible for ICAM-1 induction are poorly understood, although there is some evidence that activation of protein kinase $C$ may be involved at least in the upregulation observed on the endothelial cell surface after treatment with TNF- $\alpha .^{10}$ In addition, a specific binding site for the nuclear transcription factor- $\kappa \mathrm{B}(\mathrm{NF}-\kappa \mathrm{B})$ has been detected in the promotor region of the ICAM-1 gene. ${ }^{11}$ From the functional point of view, endothelial ICAM-1 mediates the interaction between extravasating leukocyte and the endothelium of post-capillary venules by binding to the CD11/CD18 complex. ${ }^{12}$ In monocyte/macrophages, surface ICAM-1 mediates the process of antigen presentation as well as the interaction with cell types other than endothelial cells, such as chondrocytes of the rheumatoid joint. ${ }^{13}$

Nitric oxide (NO) is a vasodilator autacoid which is produced by NO synthase from L-arginine in many mammalian cells. ${ }^{14}$ NO has many diverse biological functions in the cardiovascular, nervous and immune systems. Once formed, NO diffuses to adjacent cells where it activates soluble guanylate cyclase, resulting in the formation of cyclic guanosine monophosphate, which in turn mediates many, but not all, of the biological effects of NO. At least three isoforms of NO synthase have been cloned. The NO synthase in 
endothelial cells and neuronal cells are expressed constitutively, while activation of macrophages and other cells with proinflammatory cytokines (e.g. TNF$\alpha$, IL-1 $\beta$ ) or endotoxin (LPS) results in the expression of an inducible isoform of NO synthase (iNOS), which is functionally independent of changes in intracellular calcium. ${ }^{15}$ The iNOS gene from murine macrophages has been cloned and characterized, ${ }^{16}$ and there is evidence that activation of protein tyrosine kinase and of the nuclear transcription factor NF- $\mathrm{KB}$ is involved in the intracellular signal transduction pathway leading to the expression of this enzyme. ${ }^{17-19}$

An enhanced formation of NO following the induction of iNOS by LPS in macrophages and vascular smooth muscle cells contributes importantly to the circulatory failure (hypotension) and multiple organ dysfunction syndrome associated with septic shock. ${ }^{15,18,19}$ Moreover, during sepsis the infiltration of leukocytes plays a pivotal role in tissue damage. For instance, septic shock results in an early accumulation of polymorphonuclear leukocytes in the liver (after $3 \mathrm{~h}$ ), which is followed by an infiltration of mononuclear phagocytes (after $30 \mathrm{~h}$ ). There is evidence that that the expression of ICAM-1 may contribute to the influx of leukocytes during septic shock and, therefore, play a role in tissue damage during septic shock. ${ }^{20}$ Interestingly, circulating levels of ICAM-1 are higher in patients with septic shock than in patients with severe sepsis or sepsis without hypotension. ${ }^{21}$

In the present study, we used cultured $\mathbf{J} 774.2$ macrophages to study the signal transduction pathway, which leads to the upregulation of ICAM-1 expression by endotoxin and compared it with the one leading to an induction of iNOS.

\section{Methods}

\section{Induction of nitrite formation by endotoxin in cultured macrophages}

The mouse macrophage cell line $\mathrm{J} 774.2$ was cultured in Dulbecco's modified Eagle's medium (DMEM) supplemented with L-glutamine $(3.5 \mathrm{mM})$ and $10 \%$ foetal calf serum. ${ }^{18}$ Cells were cultured in 96-well plates with $200 \mu 1$ culture medium until they reached confluence. To induce iNOS in macrophages, fresh culture medium containing Escherichia coli lipopolysaccharide (LPS, $1 \mu \mathrm{g} / \mathrm{ml}$; serotype, 0127:B8) was added. Nitrite accumulation in the cell culture medium was measured after $24 \mathrm{~h}$. The following drugs were added to cells $30 \mathrm{~min}$ before LPS: tyrphostin AG126 $(30 \mu \mathrm{M})$, genistein $(100 \mu \mathrm{M})$, rotenone $(30 \mu \mathrm{M})$, L-1-tosylamido-2-phenylethylchloromethyl ketone (TPCK; $30 \mu \mathrm{M})$, pyrrolidine dithiocarbamate (PDTC; $25 \mu \mathrm{M})$, calpain inhibitor I $(30 \mu \mathrm{M})$, antiinflammatory cytokines such as interleukin-4 (IL-4; $100 \mathrm{ng} / \mathrm{ml}$ ), interleukin-10 (IL-10; $100 \mathrm{ng} / \mathrm{ml}$ ) or interleukin-13 (IL-13; $100 \mathrm{ng} / \mathrm{ml}$ ). The concentrations of compounds or cytokines were chosen from previous studies. ${ }^{18,19,26}$ The amount of nitrite, an indicator of NO synthesis, in the supernatant of $\mathrm{J} 774.2$ was measured by the Griess reaction 22 by adding $100 \mu 1$ of Griess reagent to $100-\mu 1$ samples of unfiltered serum or supernatant. The optical density at $550 \mathrm{~nm}$ (OD550) was measured using a Molecular Devices microplate reader (Richmond, CA, USA). Nitrite concentrations were calculated by comparison with OD550 of standard solution of sodium nitrite prepared in control culture medium. Mitochondrial respiration, an indicator of cell viability, was assessed by the mitochondrial-dependent reduction of MTT [3-(4,5-dimethylthiazol-2-yl)-2,5-diphenyltetrazolium bromide] to formazan. ${ }^{23}$ Cells in 96-well plates were incubated $\left(37^{\circ} \mathrm{C}\right)$ with MTT $(0.2 \mathrm{mg} / \mathrm{ml}$ for $60 \mathrm{~min})$. Culture medium was removed by aspiration and cells solubilized in dimethylsulfoxide by measurement of OD550 using a Molecular Devices microplate reader. Formazan production was expressed as a percentage of the values obtained from untreated cells.

\section{Western (immuno) blot analysis (iNOS)}

$\mathrm{J} 774.2$ macrophages were cultured in six-well plates $\left(37^{\circ} \mathrm{C}\right)$ and treated for $24 \mathrm{~h}$ with fresh medium alone (control) or medium containing LPS $(1 \mu \mathrm{g} / \mathrm{ml})$ to induce iNOS. To assess the effects of tyrphostin AG126, genistein, rotenone, PDTC, TPCK or calpain inhibitor I on the expression of iNOS protein induced by immunostimulants, compounds were added to the cells $30 \mathrm{~min}$ prior to LPS. After $24 \mathrm{~h}$, cells were washed with phosphate-buffered saline (PBS; pH 7.4) and incubated ( $5 \mathrm{~min}$ ) with $1 \mathrm{ml}$ of extraction buffer (pH 7.4) consisting of $50 \mathrm{mM}$ Tris- $\mathrm{HCl}, 10 \mathrm{mM}$ EDTA, $1 \%(\mathrm{v} / \mathrm{v})$ Triton $\mathrm{X}-100$, and the protease inhibitors pepstatin A $50 \mu \mathrm{M}$, leupeptin $0.2 \mathrm{mM}$ and phenylmethylsulphonylfluoride $1 \mathrm{mM}$. The cell extract was boiled for $10 \mathrm{~min}$ with gel-loading buffer (Tris, $20 \mathrm{mM}$; EDTA, $2 \mathrm{mM}$; SDS, 2\% (w/v); glycerol, 20\% (v/v); 2-mercaptoethanol, 10\% (v/v); bromophenol blue, $2 \mathrm{mg} / \mathrm{ml}$; pH 6.8) in a ratio of $1: 1(\mathrm{v} / \mathrm{v})$. Samples were centrifuged at $10000 \mathrm{~g}$ for $2 \mathrm{~min}$ before being loaded onto gradient gels $(7.5 \%$ SDS gel) and subjected to electrophoresis ( $1 \mathrm{~h}$ at $150 \mathrm{~V}$ ). The separated proteins were transferred to nitrocellulose (Bio-Rad; $1 \mathrm{~h}$ at $200 \mathrm{~V}$ ). After transfer to nitrocellulose by electrophoresis, the membranes were primed over night at $4^{\circ} \mathrm{C}$ with a polyclonal antibody raised to macrophage iNOS developed in rabbits (a generous gift from $\mathrm{Dr}$ Claire Bryant, William Harvey Research Institute, UK) ${ }^{24}$ The blots were then incubated with anti-rabbit IgG linked to horseradish peroxidase. All antibodies were used at a 1:5000 dilution. Horseradish peroxidase-conjugated secondary antibody was then added and blots developed using an enhanced horseradish peroxidase/luminol chemiluminescence reaction (ECL Western blotting detection reagents, Amersham 
International, Buckinghamshire, UK) and exposed to X-ray film for 30-60 s.

Measurement of ICAM-1 and CD11b levels by fluorescence-activated cell sorter (FACS) analysis

J774.2 macrophages were cultured in six-well plates as described above and, after they reached confluence, were washed and incubated with or without LPS $(0.01-10 \mathrm{mg} / \mathrm{ml})$ for 4 or $24 \mathrm{~h}$. At the end of the incubation period, cells were washed and removed with non-enzymatic dissociation medium and pelleted by centrifugation at $400 \mathrm{~g}$ for $15 \mathrm{~min}$ at $4^{\circ} \mathrm{C}$. Subsequently, cells were seeded in 96-well flat-bottom plates in $20 \mu 1$ of PBS supplemented with $0.2 \%$ bovine serum albumin (BSA); non-specific sites were blocked by adding $20 \mu \mathrm{l}$ of human $\operatorname{IgG}(15 \mathrm{mg} / \mathrm{ml})$ prior to the addition of $20 \mu \mathrm{l}$ of a rat anti-mouse ICAM-1 $(16 \mu \mathrm{g} / \mathrm{ml})$ or rat anti-mouse CD $11 \mathrm{~b}(16 \mu \mathrm{g} / \mathrm{ml})$ monoclonal antibody. Control wells received an equal amount of rat IgG. After $1 \mathrm{~h}$ at $4^{\circ} \mathrm{C}$, cells were washed twice with PBS/+0.2\%BSA and incubated with $40 \mu 1$ of diluted $(1: 40) \mathrm{F}\left(\mathrm{ab}^{\prime}\right)_{2}$ fragment of goat anti-rat IgG antibody conjugated to fluorescein isothiocyanate (FITC). After a further $45 \mathrm{~min}$ at $4^{\circ} \mathrm{C}$, cells were washed, resuspended in $200 \mu 1 \mathrm{PBS} /+0.2 \%$ BSA and fixed with an equal volume of $2 \%$ paraformaldehyde. FACS analysis was performed within 5 days using a FACScan II analyser (Becton-Dickinson, Mountain View, CA) with an air-cooled $100 \mathrm{~mW}$ argon ion laser tuned to $488 \mathrm{~nm}$ and Consort 32 computer running Lysis II software (Becton-Dickinson). At least 10000 events were analysed for each labelling. Data were analysed as units of fluorescence measured in the FLl channel, corrected for control binding (rat IgG), and converted to the number of mAb molecules bound per cell with reference to microbeads labelled with standard molecules of FITC (Flow Cytometry Standards Corp., Research Triangle Park, NC). ${ }^{25}$

\section{Materials}

Bacterial lipopolysaccharide ( $E$. coli serotype 0.127:B8), phosphate-buffered saline (PBS), Dulbecco's modified Eagle's medium, foetal calf serum, L-glutamine, MTT, pepstatin A, leupeptin, glycerol, 2-mercaptophanol, phenylmethylsulphonylfluoride (PMSF), Bradford reagent, bovine serum albumine, rotenone, L-1-tosylamido-2-phenylethylchloromethyl ketone (TPCK), pyrrolidine dithiocarbamate (PDTC), human IgG, Triton X-100, Trizma base, EDTA, bromophenol blue, sodium dodeyl sulphate (SDS), sulphanilamide, naphthylethylenediamide, phosphoric acid, non-enzymatic dissociation medium, and anti-rabbit IgG antibody were obtained from Sigma Chemical Co. (Poole, Dorset, UK). Pure nitrocellulose membrane $(0.45 \mu \mathrm{m})$ and filter paper were purchased from Bio-
Rad (Hertfordshire, UK). The following antibodies (AB) were purchased from Serotec (Oxford, UK): rat antimouse ICAM- 1, monoclonal rat anti-mouse CD11b and monoclonal FITC-conjugated donkey anti-rat IgG. Tyrphostin AG126 [(3-hydroxy-4-nitrobenzylidine) malononitrile or a-cyano-(3-hydroxynitro)cinnamonitrile], genistein [4,5,7-trihydroxy-isoflavone] and calpain inhibitor I ( $N$-acetyl-leu-leu-norleucinal) were from Calbiochem (Nottingham, UK). Murine recombinant IL- 4 and human recombinant IL-10 and IL-13 were a generous gift of Dr P. Grint (Schering-Plough, USA).

\section{Statistical evaluation}

Results shown are mean \pm S.E.M. from triplicate determinations (wells) from three separate experiments. One-way or two-way analysis of variance (ANOVA) followed by, if appropriate, Bonferroni multiple range test was used to compare means between groups. A $P$ value less than 0.05 was considered to be statistically significant.

\section{Results}

LPS-induced ICAM-1 and iNOS expression in J774.2 macrophages

A constitutive expression of ICAM-1 and CD11b was found on the plasma membrane of cultured $\mathrm{J} 774.2$ macrophages (Fig. 1a,b). Incubation of J774.2 macrophages with $1 \mu \mathrm{g} / \mathrm{ml}$ LPS resulted, within $4 \mathrm{~h}$, in an upregulation of ICAM-1 expression without further increase at the 24-h time-point (Fig. 1a). LPS-induced 4-h ICAM-1 expression was concentration dependent (Fig. 1c). In contrast, treatment of macrophages with different concentrations of LPS did not affect the expression of CD11b (Fig. 1b,d). Activation of J774.2 macrophages with endotoxin resulted within $24 \mathrm{~h}$ in a significant increase in nitrite in the cell supernatant (Table 1). This was mirrored by appearance of a 130-kDa protein which was recognized by a specific antibody to iNOS (Fig. 3, lane B).

In subsequent experiments, designed to elucidate similarities or differences in the LPS-induced signal transduction pathways which lead to the expression of iNOS protein and activity, and to the upregulation of ICAM-1 in J774.2 macrophages, only $1 \mu \mathrm{g} / \mathrm{ml}$ of LPS for $4 \mathrm{~h}$ (ICAM-1 expression) or $24 \mathrm{~h}$ (expression of iNOS protein and activity) was used.

\section{Involvement of tyrosine kinase}

Pretreatment of $\mathrm{J} 774.2$ macrophages with the protein tyrosine kinase inhibitors genistein $(100 \mu \mathrm{M})$ or tyrphostin AG126 $(30 \mu \mathrm{M})$ significantly attenuated the expression of iNOS protein and the formation of nitrite elicited by LPS (Table 1, Fig. 3). In contrast, neither inhibitor prevented LPS upregulation of the membrane-bound ICAM-1 (Fig. 2a). 

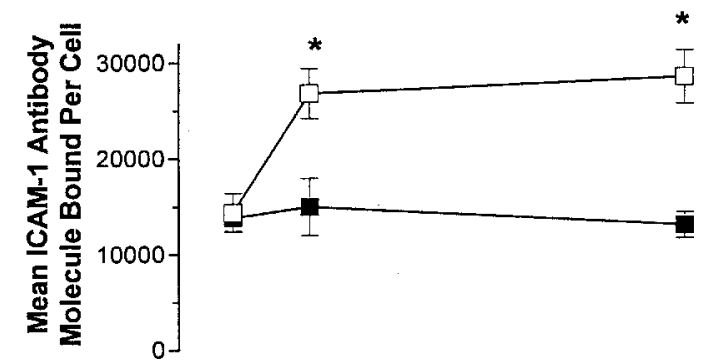

$0-$

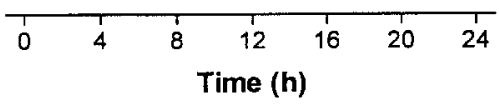

C

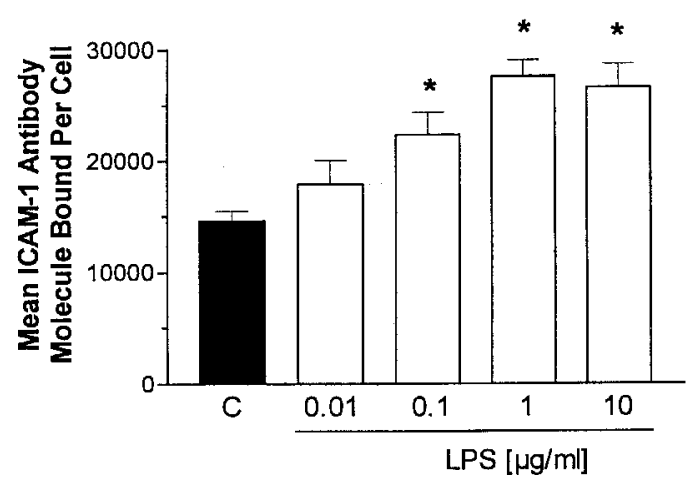

B

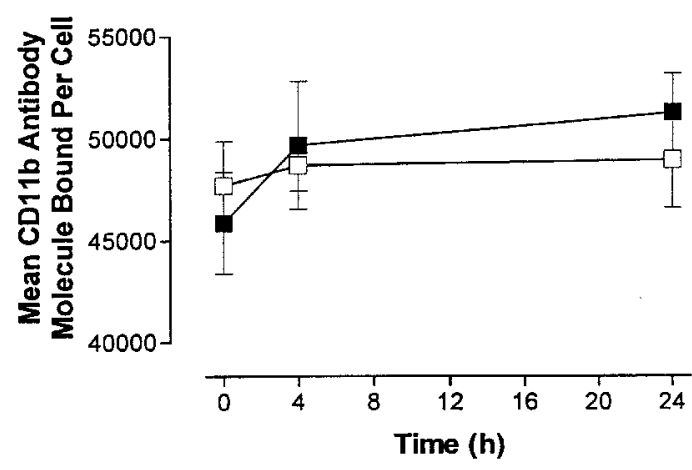

D

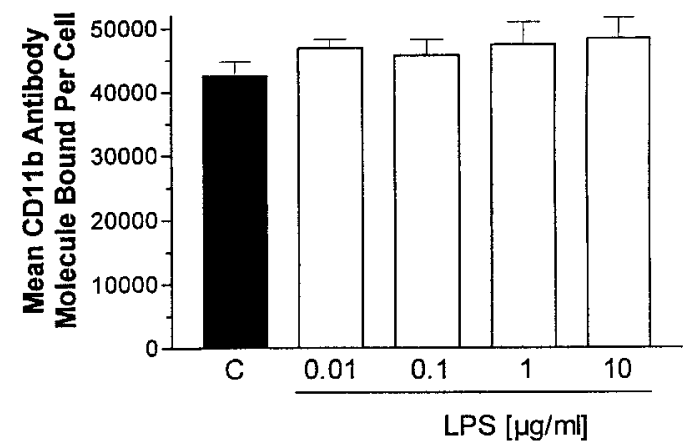

FIG. 1. Time course of the expression of (a) ICAM-1 and (b) of CD11b by J774.2 macrophages activated with endotoxin. J774.2 cells were incubated in the absence (solid squares) or presence (open squares) of LPS ( $1 \mu \mathrm{g} / \mathrm{ml}$ ) for 0,4 or $24 \mathrm{~h}$, respectively. Endotoxin caused a concentration-dependent increase in the expression of (c) ICAM-1 but not (d) of CD11b by J774.2 cells. Macrophages were treated with vehicle (C, saline; solid columns) or LPS $(0.01-10 \mu \mathrm{g} / \mathrm{ml}$; open columns) for $4 \mathrm{~h}$. At the end of experiments, adhesion molecule expression on the plasma membrane was quantified by FACS analysis. Data are expressed as mean \pm S.E.M. from triplicate determinations (wells) from three separate experimental days $(n=9)$. ${ }^{*} P<0.05$ represents significant difference when compared to control values.

Table 1. Effect of tyrphostin AG126, genistein, rotenone, L-Itosylamido-2-phenylethylchloromethyl ketone (TPCK), pyrrolidine dithiocarbamate (PDTC) or calpain inhibitor I on the increase in the formation of nitrite in supernatant of $\mathrm{J774.2}$ macrophages activated with LPS $(1 \mu \mathrm{g} / \mathrm{ml})$ for $24 \mathrm{~h}$

\begin{tabular}{lcc}
\hline Compound & Concentration $(\mu \mathrm{M})$ & Nitrite $(\mu \mathrm{M})$ \\
\hline Control & - & $1.81 \pm 0.4$ \\
LPS $(1 \mu \mathrm{g} / \mathrm{ml})$ & - & $48.4 \pm 3.6$ \\
+ tyrphostin AG126 & 30 & $17.5 \pm 2.8^{*}$ \\
+ genistein & 100 & $13.4 \pm 4.6^{*}$ \\
+ rotenone & 30 & $10.2 \pm 3.8^{*}$ \\
+ PDTC & 25 & $8.6 \pm 3.7^{*}$ \\
+ TPCK & 30 & $16.5 \pm 2.3^{*}$ \\
+ calpain inhibitor I & 30 & $14.3 \pm 3.1^{*}$ \\
\hline
\end{tabular}

Data are expressed as mean \pm S.E.M. from triplicate determinations (well) from three separate experimental days $(n=9)$. ${ }^{*} P<0.05$ represents significant difference when compared to LPS-control.

\section{Involvement of NF-KB}

Activation of NF-KB by LPS leads to the induction of iNOS in macrophages, and involves the formation of reactive oxygen intermediates. ${ }^{18}$ Accordingly, pretreatment of J774.2 cells with PDTC $(25 \mu \mathrm{M})$ or the antioxidant rotenone $(30 \mu \mathrm{M})$ prevented the increase in the formation of nitrite and the expression on iNOS protein caused by endotoxin (Table 1). Both PDTC and rotenone also attenuated the expression of ICAM1 in a concentration-dependent manner (Fig. 2b). Treatment of J774.2 cells with TPCK, a cysteine and serine protease inhibitor, or calpain inhibitor I prior to endotoxin, significantly attenuated the increase in the formation of nitrite and the expression of iNOS protein caused by LPS (Table 1, Fig. 3). In addition, the increase in the expression of ICAM-1 was also concentration-dependently attenuated by both TPCK or calpain inhibitor I (Fig. 2c). It is noteable that none 
of the drugs used modified the constitutive expression of ICAM-1 (Fig. 2a-c).

Incubation of J774.2 macrophages with LPS alone caused a small $(\sim 20 \%)$ reduction in cell viability at $24 \mathrm{~h}$, as measured by formazan formation, with no

A

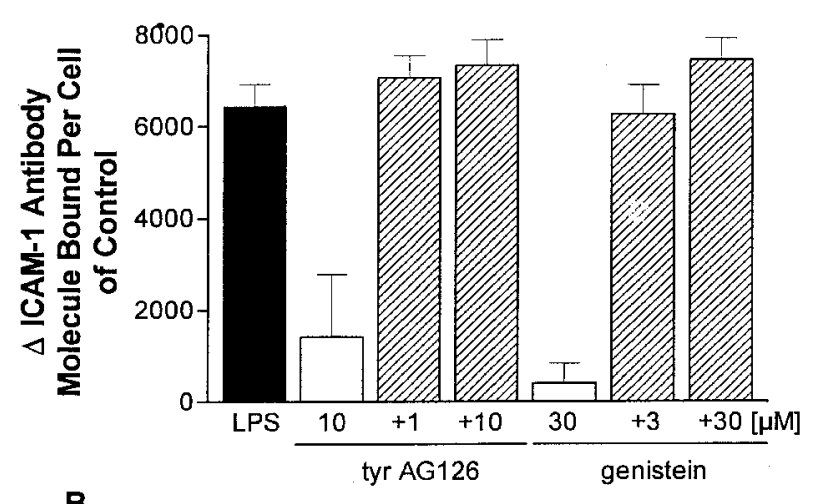

B

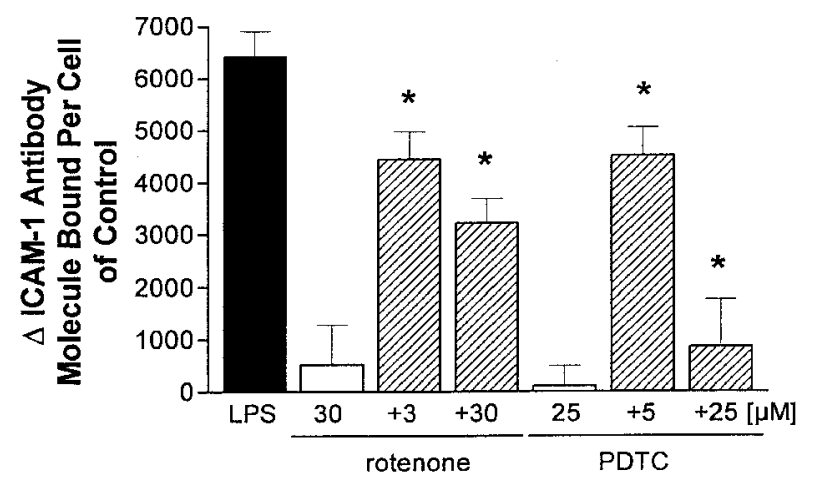

C

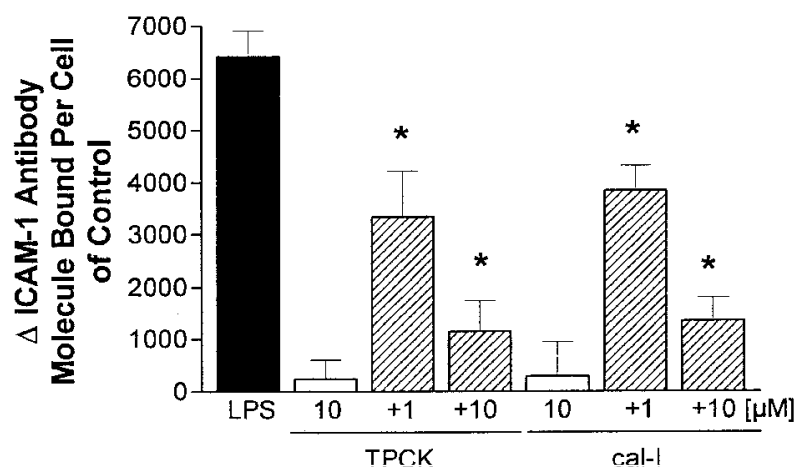

FIG. 2. Effect of (a) tyrphostin AG126 (tyr AG126) or genistein, (b) rotenone or pyrrolidine dithiocarbamate (PDTC), (c) L-1-tosylamido-2-phenylethylchloromethy ketone (TPCK) or calpain inhibitor I (cal-I) on the increase in the expression of ICAM-1 on the cell plasma membrane of J774.2 macrophages activated with LPS $(1 \mu \mathrm{g} / \mathrm{ml})$ for $4 \mathrm{~h}$. J774.2 cells were incubated with the drugs in the absence (open columns) or presence (hatched columns) of LPS. Data are expressed as mean \pm S.E.M. from triplicate determinations (wells) from three separate experimental days $(n=9)$ and are expressed as $\triangle I C A M-1$, the basal value (without LPS or drugs) being subtracted. ${ }^{*} P<0.05$ represents significant difference when compared to LPS-controls (solid column). effect at the 4-h time-point. Incubation of J774.2 cells with the drugs used did not result in a significant reduction in cell viability. Similarly, none of the drugs used attenuated the reduction in cell viability caused by LPS at $24 \mathrm{~h}$ (Table 2 ).

\section{Anti-inflammatory cytokines}

To test whether anti-inflammatory cytokines prevented the upregulation of membrane-bound ICAM-1 on macrophages, J774.2 cells were treated with IL-4, IL-10 or IL-13 (all $100 \mathrm{ng} / \mathrm{ml}$ ) prior to LPS. None of these cytokines affected either basal or LPS-induced increase in the expression of ICAM- 1 on the cell surface of $\mathrm{J} 774.2$ macrophages. In contrast, and confirming previous studies, ${ }^{26,27}$ IL-4, IL-10 or IL-13 significantly attenuated the increase in the formation of nitrite in the supernatant caused by LPS at $24 \mathrm{~h}$ (Fig. 4, Table 2).

\section{Discussion}

ICAM-1 expression at the plasma membrane of several cell types is related not only as marker of cell differentiation, but also to the degree of cell activation. Few studies have investigated the signalling pathways leading to the upregulation of ICAM-1 in mono-myelocytic cells. Using J774.2 macrophages which closely mimic primary macrophages in many aspects ${ }^{26}$ we have compared the signal transduction pathway leading to the upregulation of ICAM-1 expression with that of the increase in the expression of iNOS protein and activity caused by endotoxin.

The induction of iNOS protein and activity caused by wall fragments of Gram-negative (endotoxin), Gram-positive (lipoteichoic acid, peptidoglycan) bacteria or pro-inflammatory cytokines, such as IL-1 $\beta$ in cultured cells (e.g. macrophages), involves the phosphorylation of tyrosine residues in proteins, and is therefore prevented by the tyrosine kinase inhibitors genistein, erbstatin and tyrphostin AG126. ${ }^{28-30}$ We confirm here that two structurally distinct tyrosine kinase inhibitors, genistein (competitive inhibitor at

Table 2. Effect of interleukin-4, interleukin-10 or interleukin13 on the increase in the formation of nitrite in supernatant of J774.2 macrophages activated with LPS $(1 \mu \mathrm{g} / \mathrm{ml})$ for $24 \mathrm{~h}$

\begin{tabular}{lcc}
\hline Compound & Dose $(\mu \mathrm{g} / \mathrm{ml})$ & Nitrite $(\mu \mathrm{M})$ \\
\hline Control & - & $1.8 \pm 0.4$ \\
LPS & 1 & $52.4 \pm 2.3$ \\
+ interleukin-4 & 0.1 & $23.5 \pm 4.6^{*}$ \\
+ interleukin-13 & 0.1 & $26.8 \pm 3.3^{*}$ \\
+ interleukin-10 & 0.1 & $43.4 \pm 3.8^{*}$
\end{tabular}

Data are expressed as mean \pm S.E.M. from triplicate determinations (well) from three separate experimental days $(n=9)$. ${ }^{*} P<0.05$ represents significant difference when compared to LPS control. 


\section{$130 \mathrm{kDa}$}

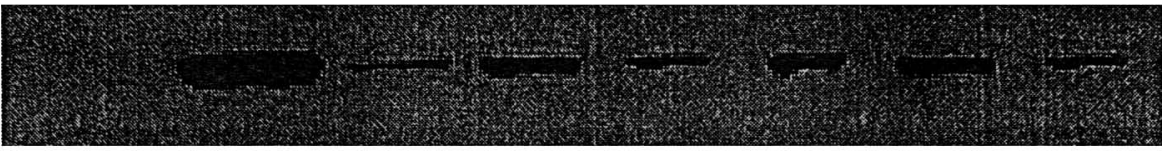

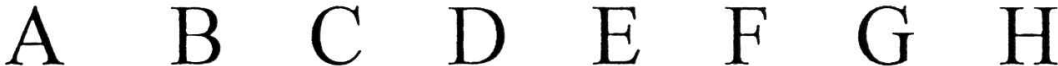

FIG. 3. Effect of tyrphostin $\mathrm{AG} 126(30 \mu \mathrm{M}$; lane $\mathrm{H})$ or genistein $(100 \mu \mathrm{M}$; lane $\mathrm{G})$, rotenone $(30 \mu \mathrm{M}$; lane $\mathrm{F})$, pyrrolidine dithiocarbamate $(25 \mu \mathrm{M}$; lane E), calpain inhibitor I (30 $\mu \mathrm{M}$; lane D) or L-1-tosylamido-2- phenylethylchloromethyl ketone $(30 \mu \mathrm{M}$; lane C) on the expression of iNOS protein in $\mathrm{J} 774.2$ macrophages caused by LPS $(1 \mu \mathrm{g} / \mathrm{ml}$; lane B) within $24 \mathrm{~h}$, as determined by Western (immuno)blot analysis. There was no iNOS protein detectable by the specific antibody against iNOS protein in unstimulated control macrophages (lane A). This immunoblot is representative for three separate experiments.

the ATP-binding site) or tyrphostin AG126 (competitive inhibitor at the substrate binding site), used at selected and validated concentrations, ${ }^{31,32}$ inhibit the expression of iNOS caused by LPS, clearly showing that tyrosine phosphorylation plays an important role in the signal transduction pathway leading to the expression of iNOS by LPS in J774.2 macrophages. In contrast, treatment of $\mathrm{J} 774.2$ macrophages with genistein or tyrphostin AG126 did not prevent the LPS-induced upregulation of the expression of membrane-bound ICAM-1. A similar finding has been described in endothelial cells. The tyrosine kinase inhibitors, genistein and tyrphostin AG1288 had no effect on the TNF- $\alpha$-induced increase in ICAM-1 expression on cultured EA.hy926 endothelial cells at $4 \mathrm{~h}$ afterTNF- $\alpha$, but significantly increased the expression of ICAM- 1 at $24 \mathrm{~h} .{ }^{33}$ In contrast, genistein and AG 1288 significantly inhibited TNF- $\alpha$-induced upregulation of ICAM-1 expression on A549 epithelial cells at $4 \mathrm{~h}$ after TNF- $\alpha$, but had no effect on ICAM-1 expression at $24 \mathrm{~h} .{ }^{34}$ These results suggest that the effects (increase, decrease or no effect) of tyrosine

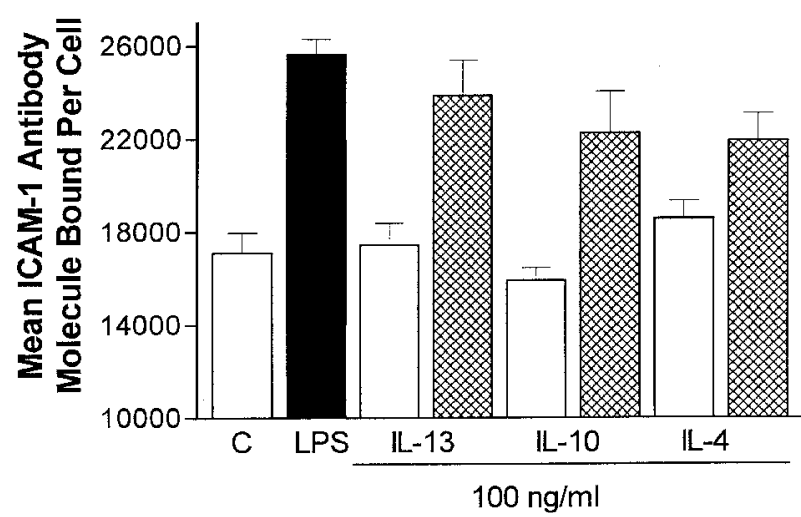

FIG. 4. Effect of interleukin-13 (IL-13), interleukin-10 (IL-10) or interleukin-4 (IL-4) on the increase in the expression of ICAM1 on the cell plasma membrane of J774.2 macrophages caused by endotoxin. J774.2 cells were incubated in the absence (open columns) or presence (hatched columns) of LPS ( $1 \mathrm{mg} / \mathrm{ml}$ ) with IL-13, IL-10 or IL-4 (all $100 \mathrm{ng} / \mathrm{ml}$ ) for $4 \mathrm{~h}$. At $4 \mathrm{~h}$ after LPS ICAM-1 expression was monitored by FACS analysis. Data are expressed as mean \pm S.E.M. from triplicate determinations (wells) from three separate experimental days $(n=9)$. ${ }^{*} P<0.05$ represents significant difference when compared to LPS controls (solid column). kinase inhibitors on the TNF- $\alpha$ - or LPS-induced upregulation of ICAM-1 expression on the plasma membrane depend on the cell type and the time of exposure to immunostimulants. Our data demonstrated that this pathway is unlikely to be activated in J774.2 cells to induce this adhesion molecule.

The expression of inducible genes including iNOS are largely controlled by proteins, such as NF- $\mathrm{KB}$, which activate transcription. ${ }^{17},{ }^{35} \mathrm{NF}-\mathrm{KB}$ is itself activated by the exposure of cells to endotoxin or TNF- $\alpha$, IL-1, IL-2 or phorbol 12-myristate 13-acetate (PMA). ${ }^{36-39}$ The most frequent form of NF-KB is a heterodimer composed of two DNA-binding proteins, namely NF-KB1 (or p50) and RelA (or p65), although other dimeric combinations also exist. ${ }^{40}$ Under physiological conditions, NF- $\mathrm{KB}$ is held (in an inactive form) in the cytoplasm by the inhibitory protein IкB$\alpha$, which avidly binds to most heterodimers including the NF-KB1/RelA heterodimer. Activation of NF-KB involves the release of the inhibitory subunit IКB- $\alpha$ from a cytoplasmic complex, which IKB forms together with the DNA-binding subunit RelA and NFKB1 $141,{ }^{42}$ and, hence, activation of NF-KB allows NF$\kappa B$ to translocate to the nucleus and to induce the expression of specific genes. ${ }^{43},{ }^{44}$ The activation of iNOS in macrophages caused by LPS or LTA is diminished by inhibitors of the activation of NF-KB, such as PDTC, TPCK, or calpain inhibitor I. ${ }^{18,30,46,47}$ However, the proteolytic degradation of IKB- $\alpha$ is inhibited with some selectivity by the cysteine protease inhibitor calpain inhibitor I, but not by other inhibitors of serine and cysteine proteases, such as chymostatin or leupeptin. ${ }^{48}$ There is evidence that activation of the promotor of ICAM- 1 by cytokines on endothelial cells critically relies on the transcription

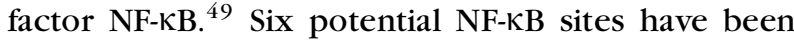
identified in the ICAM-1 5 -flanking sequence and first intron. ${ }^{50,51}$ We show that PDTC which inhibits NF-KB activation, ${ }^{52}$ not only prevented the expression of iNOS protein and activity (nitrite), but also the upregulation of ICAM-1 expression caused by LPS in $\mathrm{J} 744.2$ cells. In addition, the cysteine and serine protease inhibitors TPCK or calpain inhibitor I, which inhibit IKB protease ${ }^{48}$ prevented the LPS-induced expression of iNOS protein and activity as well as the 
upregulation of ICAM-1 expression. This implies that activation of IKB protease, known to be involved in the induction of iNOS, is also important in the upregulation of ICAM-1 expression caused by LPS on J774.2 macrophages.

One of the determinantes of NF- $\mathrm{KB}$ activation is the redox status of the cell, ${ }^{53}$ which is determined by the concentration of reactive oxygen species, including superoxide, hydrogen peroxide or hydroxyl radicals. ${ }^{52}$ There is evidence that cytokines and LPS increase the formation of cellular reactive oxygen intermediates by causing an alteration of electron flow in the mitochondria. ${ }^{53}$ We show that the antioxidant rotenone prevented the induction of iNOS protein and activity as well as the upregulation of ICAM-1 expression caused by LPS. A similar finding has been reported with the potent antioxidant $\mathrm{N}$-acetyl cysteine which inhibits the induction of iNOS protein and activity caused by LPS in rat peritoneal macrophages: this effect was linked to a reduced activation of NF-KB. ${ }^{55}$ Moreover, $N$-acetyl cysteine also inhibits ICAM-1 mRNA expression in HeLa and HaCaT cells after exposure to ionizing radiation, known to produce reactive oxygen intermediates in mammalian tissues, by inhibition of the activation of NF-KB. ${ }^{56}$ Thus, reactive oxygen intermediates, presumably by their ability to activate NF$\kappa \mathrm{B}$, play an important role in the series of events leading to the expression of iNOS and ICAM-1 induced by LPS in these cells as well as in J774.2 cells, as described here.

The anti-inflammatory cytokines IL-4, IL-10 or IL-13 have been reported to inhibit the LPS-induced formation of NO by cultured macrophages by preventing the induction of iNOS protein expression. ${ }^{26,27}$ Indeed, we confirm in this study that all three cytokines, inhibited the induction of iNOS protein and activity caused by LPS in $\mathbf{J 7 7 4 . 2}$ macrophages. Interestingly, IL-4, IL-10 or IL-13 neither affected basal nor LPS-induced expression of ICAM-1 in these cells. Therefore, there is some cell specificity in IL- 4 effects upon ICAM-1, since this cytokine directly increases ICAM-1 levels on other cell types including human dermal fibroblasts ${ }^{57}$ and human umbilical vein endothelial cells. ${ }^{58}$ Like IL-4, IL-13 also induces ICAM-1 expression in unstimulated human mast cells. ${ }^{45}$ In contrast, IL-10 and IL-13 inhibit the IL-1- or IFNK-induced expression of ICAM-1 in human monocytes, human synovial fibroblasts and human endothelial cells. ${ }^{54,59,60}$ Thus, the effect of the anti-inflammatory cytokines IL-4, IL-10 or IL-13 on the expression of ICAM-1 depends on the cell system and the stimulus employed for activation.

In conclusion, this study demonstrated that increase in ICAM-1 and iNOS expression in J774.2 macrophages by endotoxin involves reactive oxygen intermediates, and the activation of NF-KB. In contrast to the signal transduction pathway leading to the induction of iNOS, activation of protein tyrosine kinase is not involved in the LPS-induced upregulation of ICAM-1 expression in J774.2 macrophages, and consequently this pathway is not sensitive to antiinflammatory interleukins.

\section{References}

1. Rothlein R, Dustin ML, Marlin SD, Springer A. A human intercellular adhesion molecule (ICAM-1) distinct from LFA-1. J. Immunol 1986: 137: 1270-1274.

2. Springer TA. Adhesion receptors of the immune system. Nature 1990: 346: 425-434.

3. Staunton DE, Marlin SD, Stratowa C, Dustin ML, Springer TA. Primary structure of ICAM-1 demonstrates interaction between members of the immunoglobulin and integrin supergene families. Cell 1988: 52: 925-933

4. Colic M, Drabek D. Expression and function of intercellular adhesion molecule 1 (ICAM-1) on rat thymic macrophages in culture. Immunol Lett 1991: 28: 251-257.

5. Watson C, Whittaker S, Smith N, Vora AJ, Dumonde DC, Brown KA. IL-6 acts on endothelial cells to preferentially increase their adherence for lymphocytes. Clin Exp Immunol 1996: 105: 112-119.

6. Devaux B, Scholz D, Hirche A, Klovekorn WP, Schaper J. Upregulation of cell adhesion molecules and the presence of low grade inflammation in human chronic heart failure. Eur Heart J 1997: 18: 470-479.

7. Yasukawa H, Imaizumi T, Matsuoka H, Nakashima A, Morimatsu M. Inhibition of intimal hyperplasia after balloon injury by antibodies to intercellular adhesion molecule-1 and lymphocyte function-associated antigen-1. Circulation 1997: 95: 1515-1522.

8. Tailor A, Das AM, Getting SJ, Flower RJ, Perretti M. Subacute treatment of rats with dexamethasone reduces ICAM-1 levels on circulating monocytes. Biochem Biophys Res Commun 1997: 231: 675-678.

9. Perretti M, Wheller SK, Harris JG, Flower RJ. Modulation of ICAM-1 levels on U-937 cells and mouse macrophages by interleukin-1 beta and dexamethasone. Biochem Biophys Res Commun 1996: 223: 112-117.

10. Lane TA, Lanikin, GE, Wancewicz EV. Protein kinase C inhibitors block the enhanced expression of intercellular adhesion molecule-1 on endothelial cells activated by interleukin-1, lipopolysaccharide and tumor necrosis factor. Biochem Biophys Res Commun 1990: 172: 1273-1281

11. Caldenhoven E, Liden J, Wissink S, Van de Stolpe A, Raaijmakers J, Koenderman L, Okiet S, Gustafsson JA, Van der Saag PT. Negative crosstalk between RelA and the glucocorticoid receptor: a possible mechanism for the antiinflammatory action of glucocorticoids. Mol Endocrinol 1995: 9: 401-412.

12. Diamond MS, Staunton DE, Marlin SD, Springer TA. Binding of the integrin Mac-1 (CD11b/CD18) to the third immunoglobulin-like domain of ICAM-1 (CD54) and its regulation by glycosylation. Cell 1991: 65: 961-971.

13. Horner A, Davies ME, Franz B. Chondrocyte-peripheral blood mononuclear cell interactions: the role of ICAM-1. Immunology 1995: 86: 584-590.

14. Moncada S, Higgs A. The L-arginine-nitric oxide pathway. New Engl J Med 1993: 329: 2002-2012.

15. Thiemermann $C$. The role of the L-arginine: nitric oxide pathway in circulatory shock. Adv Pharmacol 1994: 28: 45-79.

16. Lowenstein CJ, Glatt CS, Bredt DS, Snyder SH. Cloned and expressed macrophage nitric oxide synthase contrasts with the brain enzyme. Proc Natl Acad Sci USA 1992: 89: 6711-6715.

17. Xie Q, Kashiwabara Y, Nathan C. Role of transcription factor NF- $\kappa B / R e$ in induction of nitric oxide. J Biol Chem 1994: 269: 4705-4708.

18. Ruetten H, Thiemermann C. Attenuation by calpain inhibitor I, an inhibitor of the proteolysis of IKB, of the circulatory failure and multiple organ dysfunction caused by endotoxin in the rat. BrJ Pharmacol 1997 : 121: $695-704$

19. Ruetten H, Thiemermann C. Effects of tyrphostins and genistein on the circulatory failure and organ dysfunction caused by endotoxin in the rat: a possible role for protein tyrosine kinase. Br J Pharmacol 1997: 122: 59-70.

20. Van Oosten M, van de Bilt E, de Vries HE, van BerkelTJ, Kuiper J. Vascular adhesion molecule-1 and intercellular adhesion molecule-1 expression on rat liver cells after lipopolysaccharide administration in vivo. Hepatology 1995: 22: 1538-1546.

21. Sessler CN, Windsor AC, Schwartz M, Watson L, Fisher BJ, Sugerman HJ, Fowler AA 3rd. Circulating ICAM-1 is increased in septic shock. Am J Resp Crit Care Med 1995: 151: 1420-1427.

22. Green LC, Ruiz de Luzuriaga K, Wagner DA. Nitrate biosynthesis in man. Proc Natl Acad Sci USA 1981: 78: 7764-7768.

23. Mosmann T. Rapid colorimetric assay for cellular growth and survival: application to proliferation and cytotoxicity assays. J Immunol Methods 1983: 65: 55-63. 
24. Bryant CE, Tomlinson A, Mitchell JA, Thiemermann C, Vane JR. Nitric oxide synthase in the rat fallopian tube is regulated during the estrouscycle. J Endocrinol 1995: 146: 149-157.

25. Le-Bouteiller PP, Mishal Z, Lemonnier FA, Kourilsky FM. Quantification by flow cytofluorimetry of HLA class I molecules at the surface of murine cells transformed by cloned HLA genes. I Immunol Methods 1993: 61: 301-315.

26. Perretti M, Szabo C, Thiemermann C. Effect of interleukin-4 and interleukin-10 on leucocyte migration and nitric oxide production in the mouse. Br J Pharmacol 1995: 116: 2251-2257.

27. Ruetten H, Thiemermann, C. Interleukin-13 is a more potent inhibitor of the expression of inducible nitric oxide synthase in smooth muscle cells than in macrophages: a comparison with interleukin- 4 and interleukin-10 Sbock 1997: 8: 409-414

28. Dong Z, Qi X, Fidler IJ. Protein tyrosine kinase inhibitors decrease the induction of nitric oxide synthase activity in lipopolysaccharideresponsive and non-responsive murine macrophages. J Immunol 1993 151: 2717-2724.

29. Marczin N, Papapetropoulos A, Catravas JD. Tyrosine kinase inhibitors supress endotoxin- and IL-1 beta-induced NO synthesis in aortic smooth muscle cells. Am J Physiol 1993: 265: H1014-1018.

30. Kengatharan M, De Kimpe SJ, Thiemermann C. Analysis of the signal transduction in the induction of nitric oxide synthase by lipotoic acid in macrophages. Br J Pharmacol 1996: 117: 1163-1170.

31. Levitzki A, Gilon C. Tyrphostins as molecular tools and potential antiproliferative drugs. Trends Pharmacol Sci 1991: 12: 171-174.

32. Novogrodsky A, Vanichkin A, Patya M, Gazit A, Osherov N, Levitzki A. Prevention of lipopolysaccharide-induced lethal toxicity by tyrosine kinase inhibitors. Science 1994: 264: 1319-1322.

33. Wheller SK, Perretti M. Dexamethasone inhibits cytokine-induced intercellular adhesion molecule-1 upregulation on endothelial cell lines. Eur J Pharmacol 1997: 331: 65-71.

34. Burke-Gaffney A, Hellewell PG. Tumour necrosis factor-alpha-induced ICAM-1 expression in human vascular endothelial and lung epithelial cells: modulation by tyrosine kinase inhibitors. Br J Pharmacol 1996: 119: 1149-1158.

35. Grimm S, Bauerle PA. The inducible transcription factor NF-kappa B: structure function relationship of its protein subunit. Biochem J 1993: 290: 297-308.

36. Sen R, Baltimore D. Inducibility of kappa immunoglobulin enhancer binding protein NF-kappa B by a post-translation mechanism. Cell 1986: 47: $921-928$.

37. Lowenthal JW, Ballard, DW, Boehnlein E, Greene WC. Tumor necrosis factor alpha induces proteins that bind specifically to kappa B-like enhancer elements and regulate interleukin 2 receptor alpha-chain gene expression in primary human T lymphocytes. Proc Natl Acad Sci USA 1989: 86: 2331-2335.

38. Arima N, Kuziel WA, Gardine TA, Greene WC. Il-2-induced signal transduction involves the activation of nuclear NF-kappa B expression. $J$ Immunol 1992: 149: 83-91.

39. Henkel T, Machleidt T, Alkalay I, Kroenke M, Ben-Neriah Y, Bauerle PA Rapid proteolysis of IKB-a is necessary for activation of transcription factor NF-KB. Nature 1993: 365: 182-185.

40. Siebenlist U, Franzoso G, Brown K. Structure, regulation and function of NF-kappa B. Annu Rev Cell Biol 1994: 10: 405-455.

41. Baeuerle PA, Baltimore D. Activation of DNA-binding activity in an apparently cytoplasmic precursor of the NF-kappa B transcription factor. Cell 1988: 53: 211-217.

42. Baeuerle PA, Baltimore D. I kappa B: a specific inhibitor of the NF-kappa B transcription factor. Science 1988: 242: 540-546.

43. Sun SC, Ganchi PA, Ballard DW, Greene WC. NF-kappa B controls expression of inhibitor I kappa B alpha: evidence for an inducible autoregulatory pathway. Science 1993: 259: 1912-1915.

44. Miyamoto S, Maki M, Schmitt MJ, Hatanaka M, Verma IM. Tumor necrosis factor a-induced phosphorlyation of IKBa is a signal for its degradation but not dissociation from NF-kB. Proc Natl Acad Sci USA 1994: 91 $12740-12744$.
45. Nilsson G, Nilsson K. Effects of interleukin (IL)-13 on immediate-early response gene expression, phenotype and differentiation of human mast cells. Comparison with IL-4. Eur J Immunol 1995: 25: 870-873.

46. Griscavage JM, Wilk S, Ignarro LJ. Serine and cysteine proteinase inhibitors prevent nitric oxide production by activated macrophages by interfering with transcription of the inducible NO synthase gene. Biochem Biophys Res Commum 1995: 215: 721-729.

47. Griscavage TM, Wilk S, Ignarro LJ. Inhibitors of proteosome pathway interfere with induction of nitric oxide synthase in macrophages by blocking activation of transcription factor NF-kappa B. Proc Natl Acad Sci USA 1996: 93: 3308-3312.

48. Lin YC, Brown K, Siebenlist U. Activation of NFKB requires proteolysis of

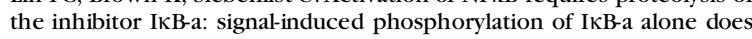
not release active NFKB. Proc Natl Acad Sci USA 1995: 92: 552-556.

49. Ledebur HC, Parks TP. Transcriptional regulation of the intercellular adhesion molecule-1 gene by inflammatory cytokines in human endothelial cells. Essential roles of a variant NF-kappa B site and p65 homodimers. J Biol Chem 1995: 270: 933-943.

50. Degitz K, Li LJ, Caughman SW. Cloning and characterization of the 5 -transcriptional regulatory region of the human intercellular adhesion molecule 1 gene. J Biol Chem 1991: 266: 14024-14030.

51. Van de Stolpe A, Caldenhoven E, Stade BG, Koenderman L, Raaijmakers JA, Johnson JP, van der Saag PT. 12-O-Tetradecanoylphorbol-13-acetateand tumor necrosis factor alpha-mediated induction of intercellular adhesion molecule- 1 is inhibited by dexamethasone. Functional analysis of the human intercellular adhesion molecular-1 promoter. $\mathrm{J} \mathrm{Biol} \mathrm{Chem}$ 1994: 269: 6185-6192.

52. Schreck R, Rieber P, Baeuerle PA. Reactive oxygen intermediates as apparently widely used messengers in the activation of the NF-kappa $B$ transcription factor and HIV-1. EMBO J 1991: 10: 2247-2258.

53. Baeuerle PA, Henkel T. Function and activation of NF-kappa B in the immune system. Annu Rev Immunol 1994: 12: 141-179.

54. Lindner H, Holler E, Gerbitz A, Johnson JP, Bornkamm GW, Eissner G. Influence of bacterial endotoxin on radiation-induced activation of human endothelial cells in vitro and in vivo: interleukin-10 protects against transendothelial migration. Transplantation 1997: 64 : 1370-1373.

55. Pahan K, Sheikh FG, Namboodiri AM, Singh I. $N$-Acetyl cysteine inhibits induction of no production by endotoxin or cytokine stimulated rat peritoneal macrophages, C6 glial cells and astrocytes. Free Radic Biol Med 1998: 24: 39-48.

56. Baeuml H, Behrends U, Peter RU, Mueller S, Kammerbauer C, Caughman SW, Degitz K. Ionizing radiation induces, via generation of reactive oxygen intermediates, intercellular adhesion molecule-1 (ICAM-1) gene transcription and NF kappa B-like binding activity in the ICAM-1 transcriptional regulatory region. Free Radic Res 1997: 27: 127-142.

57. Piela-Smith TH, Broketa G, Hand A, Korn JH. Regulation of ICAM-1 expression and function in human dermal fibroblasts by IL-4.J Immunol 1992: 148: 1375-1381.

58. Konstantopoulos K, Kukreti S, Smith CW, McIntire LV. Endothelial P-selectin and VCAM-1 each can function as primary adhesive mechanisms for T cells under conditions of flow. J Leukocyte Biol 1997: 61: $179-187$.

59. Sironi M, Sciacca FL, Matteucci C, Conni M, VecchiA, Bernasconi S, Minty A, Caput D, Ferrara P, Colotta F. Regulation of endothelial and mesothelial cell function by interleukin-13: selective induction of vascular cell adhesion molecule-1 and amplification of interleukin- 6 production. Blood 1994: 84: 1913-1921.

60. Song S, Ling-Hu H, Roebuck KA, Rabbi MF, Donnelly RP, Finnegan A. Interleukin-10 inhibits interferon-gamma-induced intercellular adhesion molecule-1 gene transcription in human monocytes. Blood 1997: 89: 4461-4469.

\section{Received 8 January 1999; accepted 19 January 1999}




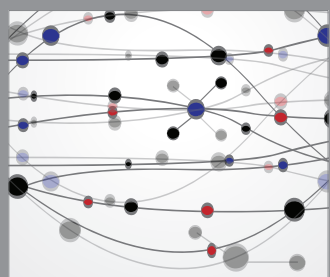

The Scientific World Journal
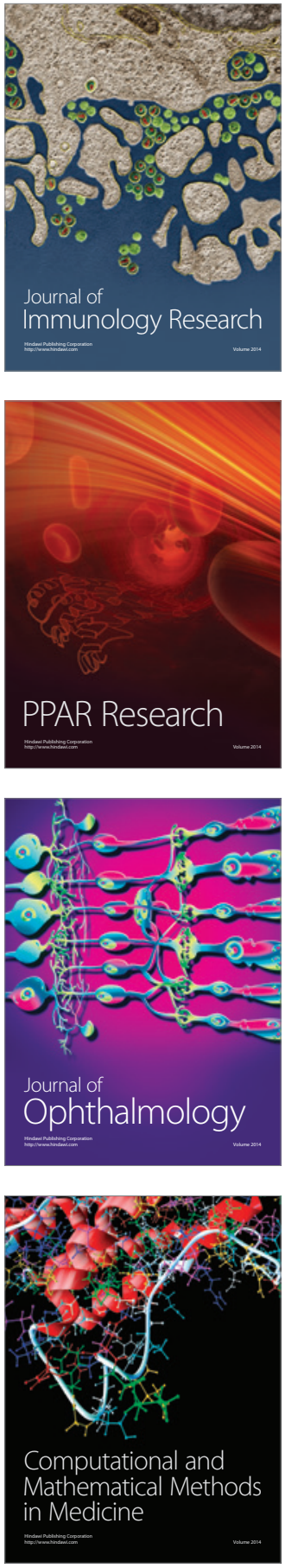

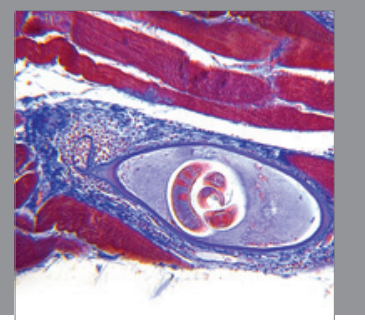

Gastroenterology

Research and Practice
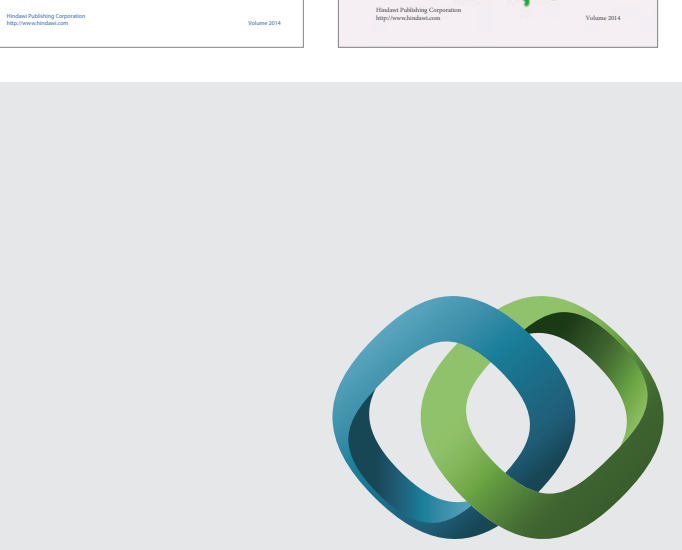

\section{Hindawi}

Submit your manuscripts at

http://www.hindawi.com
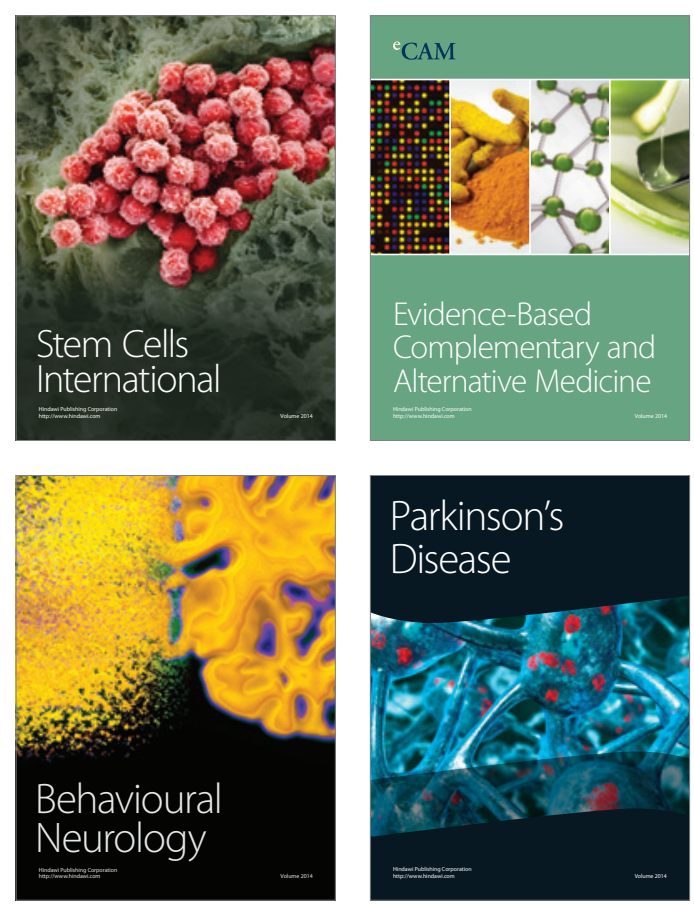

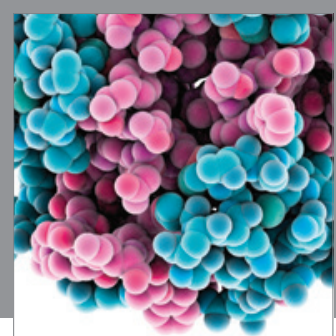

Journal of
Diabetes Research

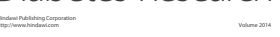

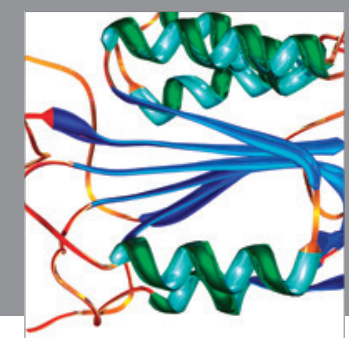

Disease Markers
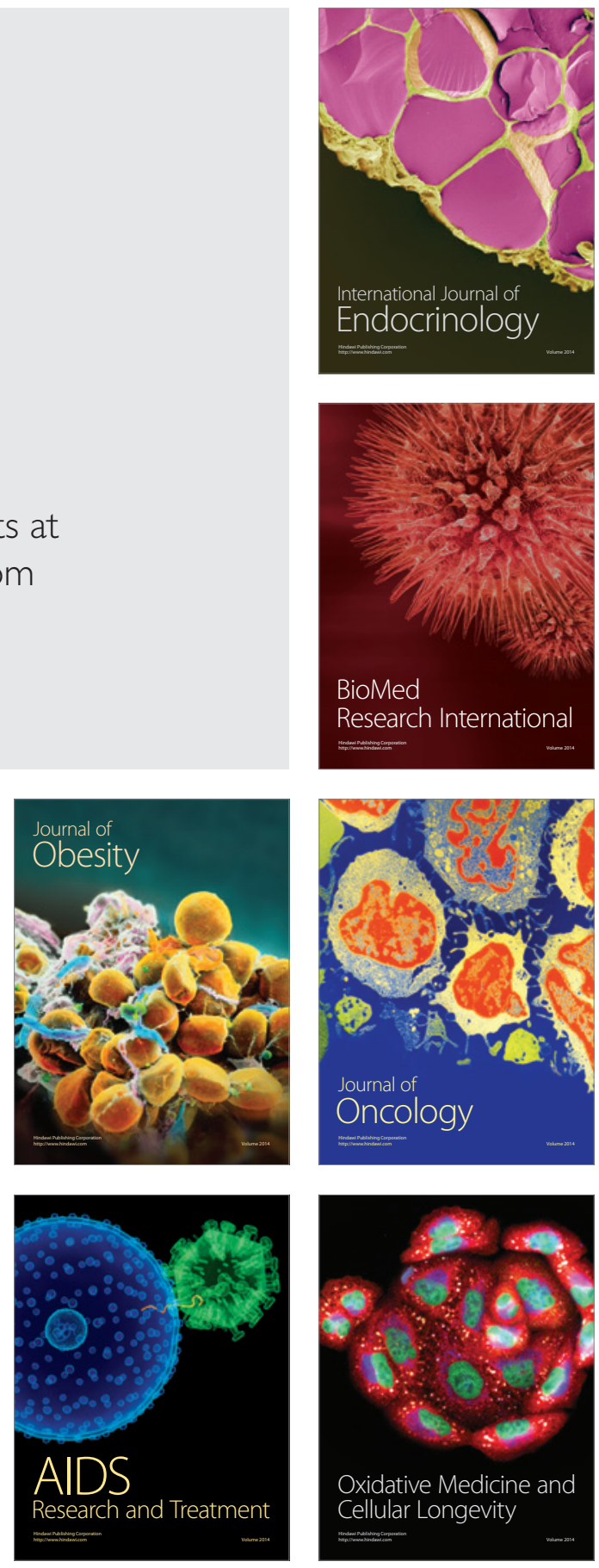